Prepared in cooperation with the Electric Power Research Institute

\title{
Evaluation of Acoustic Doppler Current Profiler to Measure Discharge at New York Power Authority's Niagara Power Project, Niagara Falls, New York
}

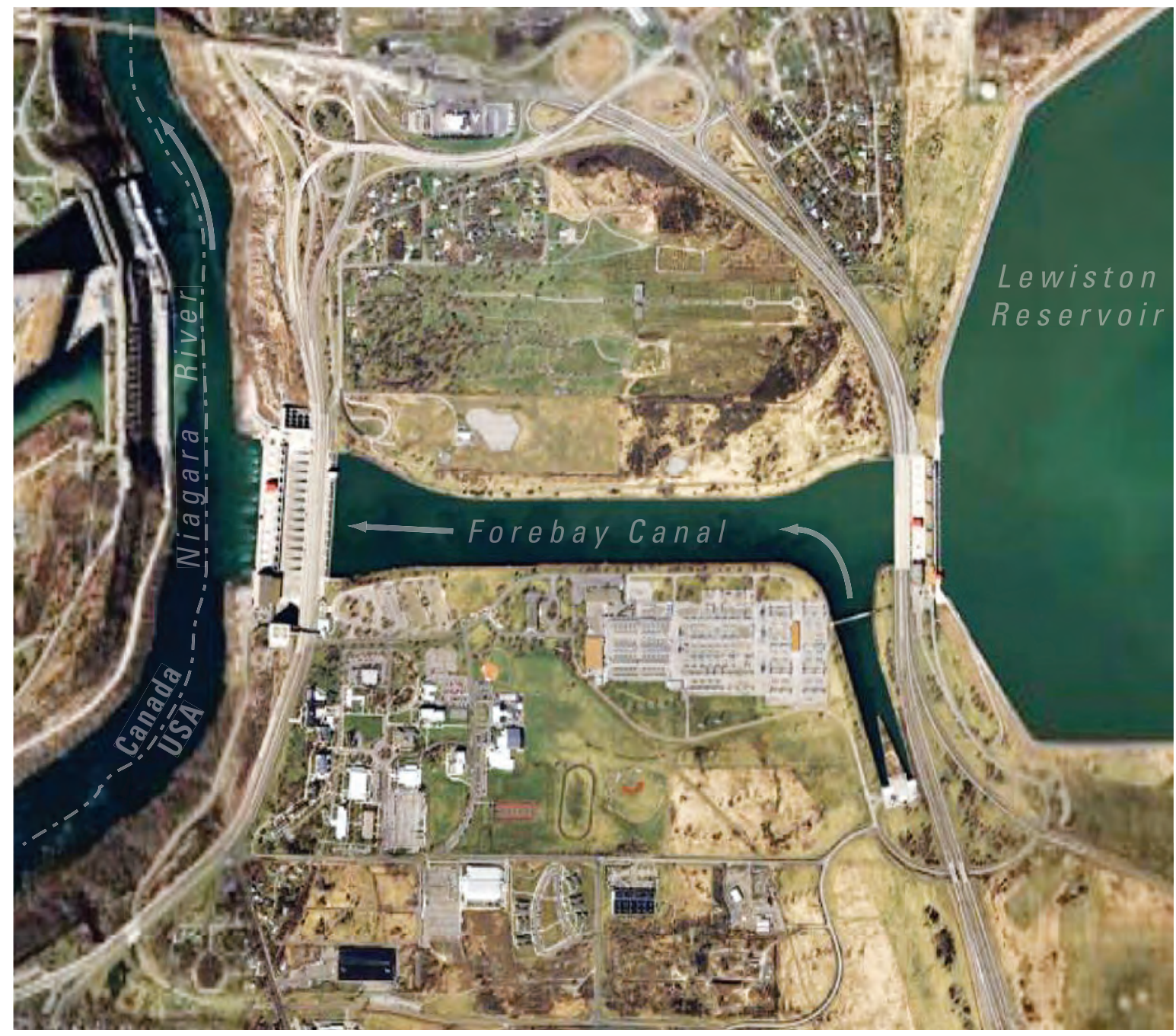

Open-File Report 2007-1187 
Cover. Aerial image of Niagara River, Forebay (diversion) Canal and the Lewiston Reservoir at the New York Power Authority's Niagara Project, Niagara Falls, New York. (Source of the graphic is from the NYS GIS Clearinghouse.) 


\section{Evaluation of Acoustic Doppler Current Profiler to Measure Discharge at New York Power Authority's Niagara Power Project, Niagara Falls, New York}

By Henry J. Zajd, Jr.

Prepared in cooperation with the Electric Power Research Institute

Open-File Report 2007-1187 


\section{U.S. Department of the Interior \\ DIRK KEMPTHORNE, Secretary}

\section{U.S. Geological Survey \\ Mark D. Myers, Director}

U.S. Geological Survey, Reston, Virginia: 2007

For more information on the USGS - the Federal source for science about the Earth, its natural and living resources, natural hazards, and the environment:

World Wide Web: http://www.usgs.gov

Telephone: 1-888-ASK-USGS

Suggested citation:

Zajd, H.J., Jr., 2007, Evaluation of Acoustic Doppler Current Profiler to measure discharge at New York Power Authority's Niagara Power Project, Niagara Falls, New York: U.S. Geological Survey Open-File Report 2007-1187, 21 p., Online Only

Any use of trade, product, or firm names is for descriptive purposes only and does not imply endorsement by the U.S. Government.

Although this report is in the public domain, permission must be secured from the individual copyright owners to reproduce any copyrighted material contained within this report. 


\section{Contents}

Abstract

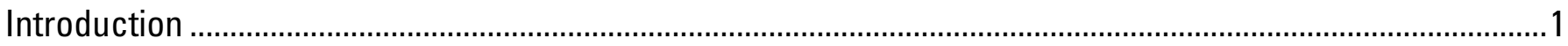

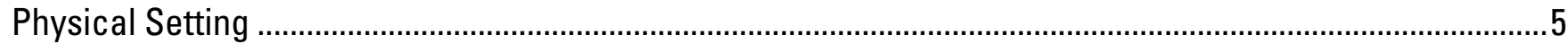

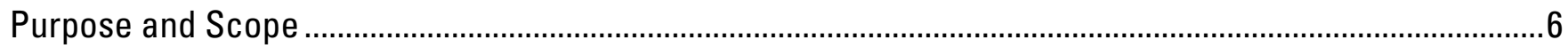

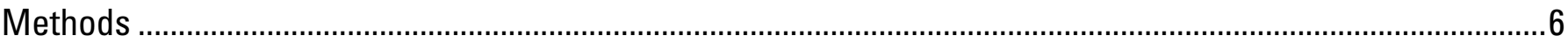

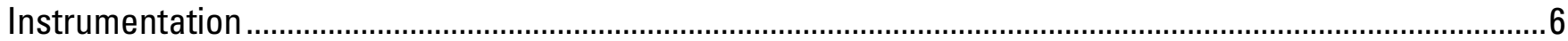

Measurement Procedures .....................................................................................................................12

New York Power Authority Method of Calculating Water Diversion............................................................13

Acoustic Doppler Current Profiler Measurements in Relation to New York Power Authority

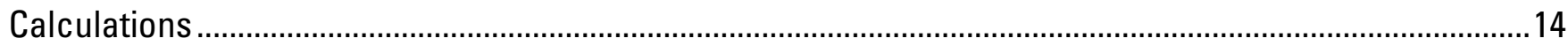

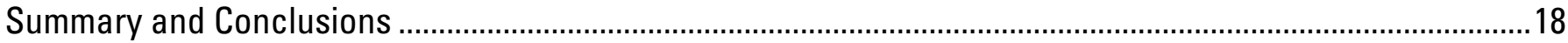

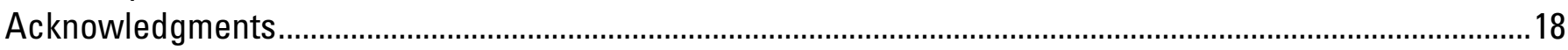

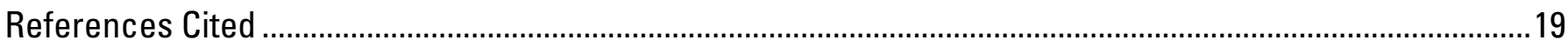

Appendix. Acoustic Doppler Current Profiler transect start and end times and durations, recorded channel velocities, flow directions, and total discharges, at New York Power Authority Niagara Power Project generation facility, Niagara Falls, N.Y., November 6-8, 2006.

\section{Figures}

1. Map showing location of Buffalo and Niagara Falls, Lake Erie and Lake Ontario, and relation to study area near New York Power Authority Niagara Power Project generation facility, Niagara Falls, N.Y.

2. Map showing location of Lewiston Reservoir, Forebay Canal, Robert Moses Power Plant, and "Pant Leg" diversion channel area near New York Power Authority Niagara Power Project generation facility, Niagara Falls, N.Y.

3. Map showing location of "Pant Leg" diversion channel and walkway discharge measuring section at the New York Power Authority Niagara Power Project generation facility, Niagara Falls, N.Y.

4. Photographs showing: (A) Acoustic Doppler Current Profiler (ADCP) mounted on a tethered trimaran platform that floats on the water surface to measure water velocity and $(B)$ ADCP floating in "Pant Leg" diversion channel downstream from walkway bridge at New York Power Authority Niagara Power Project generation facility, Niagara Falls, N.Y.

5. Graphs showing examples of graphical output (profiles) from Acoustic Doppler Current Profiler $(A D C P)$ showing measured water velocity magnitude, in feet per second ( $\mathrm{ft} / \mathrm{s})$, and direction, in degrees $\left({ }^{\circ}\right)$, based on raw ADCP data collected at "Pant Leg" diversion channel near New York Power Authority Niagara Power Project generation facility, Niagara Falls, N.Y., November 7, 2006.

6. Photographs showing measurement setup: Price-AA current meter and sounding weight, E-reel, and E-crane used for standard U.S. Geological Survey current-meter discharge measurement from bridges and used at the "Pant Leg" diversion channel near New York Power Authority Niagara Power Project generation facility, Niagara Falls, N.Y. 
7. Vertical section of water column showing locations of individual Price-AA current-meter measurements from bridge walkway near the end of Niagara Power Authority "Pant Leg" diversion channel, November 7, 2006, 10:30-12:05 Eastern Standard Time..

8. Plots showing Acoustic Doppler Current Profiler discharge measurements and New York Power Authority (NYPA)-calculated discharges obtained during the four measurement sessions at "Pant Leg" diversion channel near NYPA Niagara Power Project generation facility, Niagara Falls, N.Y., November 6-8, 2006

9. Niagara River Diversion histogram showing 2005-2006 calendar year and discharge rates during Acoustic Doppler Current Profiler measurements in "Pant Leg" diversion channel on November 6, 7, and 8, 2006, near New York Power Authority Niagara Power Project generation facility, Niagara Falls, N.Y.

10. Vertical section of "Pant Leg" diversion channel showing area for which the discharge was measured, area for which the discharge theoretically should have been estimated, and area where the discharge was estimated

\section{Table}

1. Data from comparison of Acoustic Doppler Current Profiler discharge measurements with discharge calculations by New York Power Authority at Niagara Power Project generation facility, Niagara Falls, N.Y., November 6-8, 2006

\section{Conversion Factors}

\begin{tabular}{lll}
\hline \multicolumn{1}{c}{ Multiply } & \multicolumn{1}{c}{ By } & \multicolumn{1}{c}{ To obtain } \\
\hline & Length & \\
\hline inch (in.) & 2.54 & centimeter $(\mathrm{cm})$ \\
foot (ft) & 0.3048 & meter \\
mile (mi) & 1.609 & kilometer \\
\hline & Flow rate & \\
\hline cubic foot per second $\left(\mathrm{ft}^{3} / \mathrm{s}\right)$ & 0.02832 & cubic meter per second \\
\hline
\end{tabular}

Horizontal coordinate information is referenced to North American Datum of 1983 (NAD 83). 


\title{
Evaluation of Acoustic Doppler Current Profiler to Measure Discharge at New York Power Authority's Niagara Power Project, Niagara Falls, New York
}

\author{
By Henry J. Zajd, Jr.
}

\begin{abstract}
The need for accurate real-time discharge in the International Niagara River hydro power system requires reliable, accurate and reproducible data. The U.S. Geological Survey has been widely using Acoustic Doppler Current Profilers (ADCP) to accurately measure discharge in riverine channels since the mid-1990s. The use of the ADCP to measure discharge has remained largely untested at hydroelectric-generation facilities such as the New York Power Authority's (NYPA) Niagara Power Project in Niagara Falls, N.Y. This facility has a large, engineered diversion channel with the capacity of high volume discharges in excess of 100,000 cubic feet per second $\left(\mathrm{ft}^{3} / \mathrm{s}\right)$. Facilities such as this could benefit from the use of an ADCP, if the ADCP discharge measurements prove to be more time effective and accurate than those obtained from the flowcalculation techniques that are currently used.

Measurements of diversion flow by an ADCP in the "Pant Leg" diversion channel at the Niagara Power Project were made on November 6, 7, and 8, 2006, and compared favorably (within 1 percent) with those obtained concurrently by a conventional Price-AA current-meter measurement during one of the ADCP measurement sessions. The mean discharge recorded during each 2-hour individual ADCP measurement session compared favorably with (3.5 to 6.8 percent greater than) the discharge values computed by the flow-calculation method presently in use by NYPA. The use of ADCP technology to measure discharge could ultimately permit increased power-generation efficiency at the NYPA Niagara Falls Power Project by providing improved predictions of the amount of water (and thus the power output) available.
\end{abstract}

\section{Introduction}

The New York Power Authority (NYPA) and its Canadian counterpart, Ontario Hydro of Canada, abide by an international treaty on the amounts of water that may be diverted from the upper Niagara River to the two hydropower plants. Accurate measurements of the quantity of water diverted from the Niagara River for hydroelectric power generation are needed to fulfill the terms of this agreement. NYPA wants to know whether Acoustic Doppler technology is suitable for this application. Therefore, in November 2006, the U.S. Geological Survey (USGS), in cooperation with the Electric Power Research Institute (EPRI) and NYPA, ran a 3-day test to assess the accuracy and feasibility of using an Acoustic Doppler Current Profiler (ADCP) to measure discharge in the "Pant Leg," a large, engineered diversion channel at the NYPA Niagara Power Project, under high-flow conditions (figs. 1 and 2). The availability of real-time discharge data 
from this location would improve the prediction of the amount of water (and thus the power output) available to meet power-generation requirements and could increase the efficiency of watermanagement administration for both countries. 


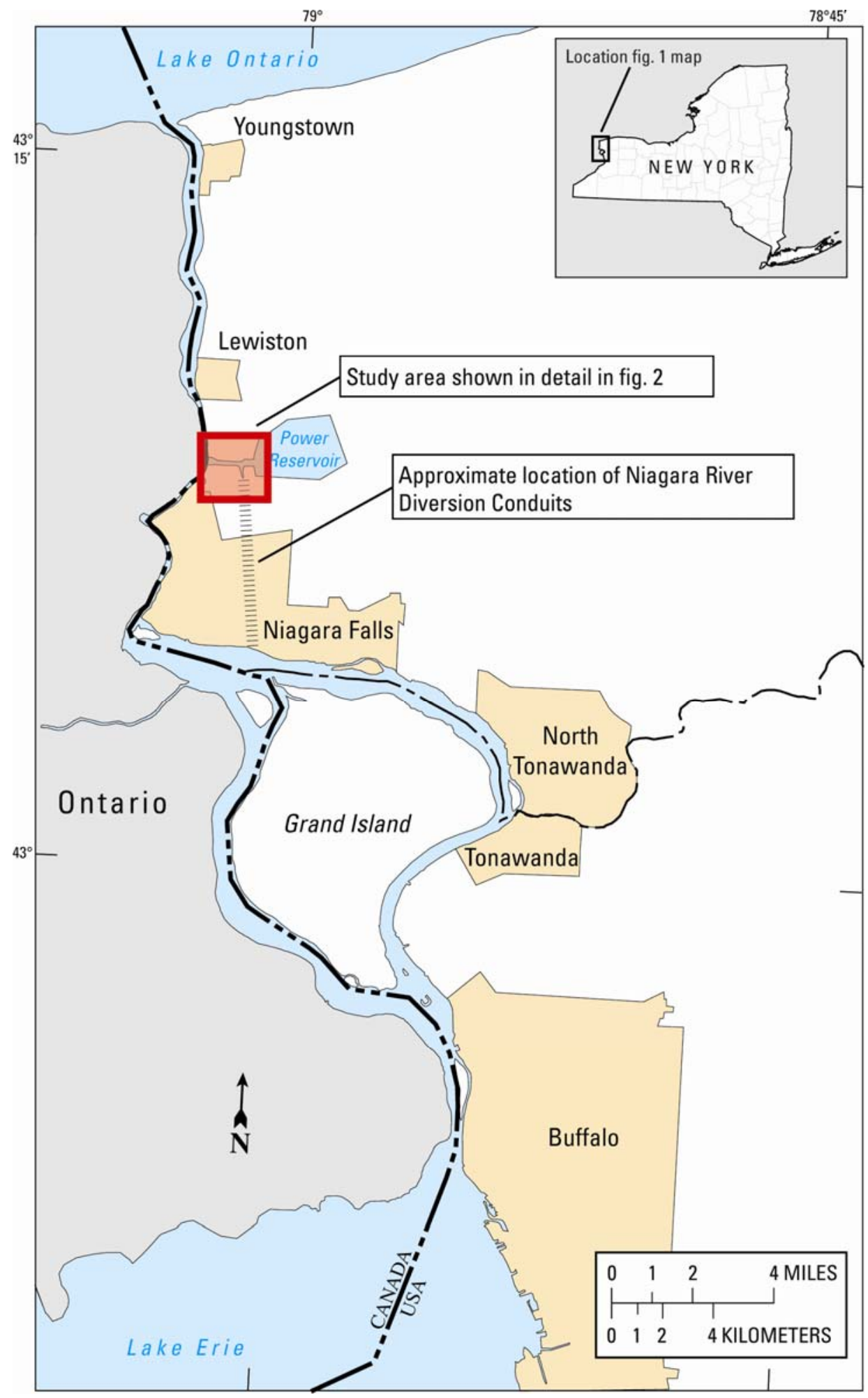

Figure 1. Location of Buffalo and Niagara Falls, Lake Erie and Lake Ontario, and relation to study area near New York Power Authority Niagara Power Project generation facility, Niagara Falls, N.Y. 


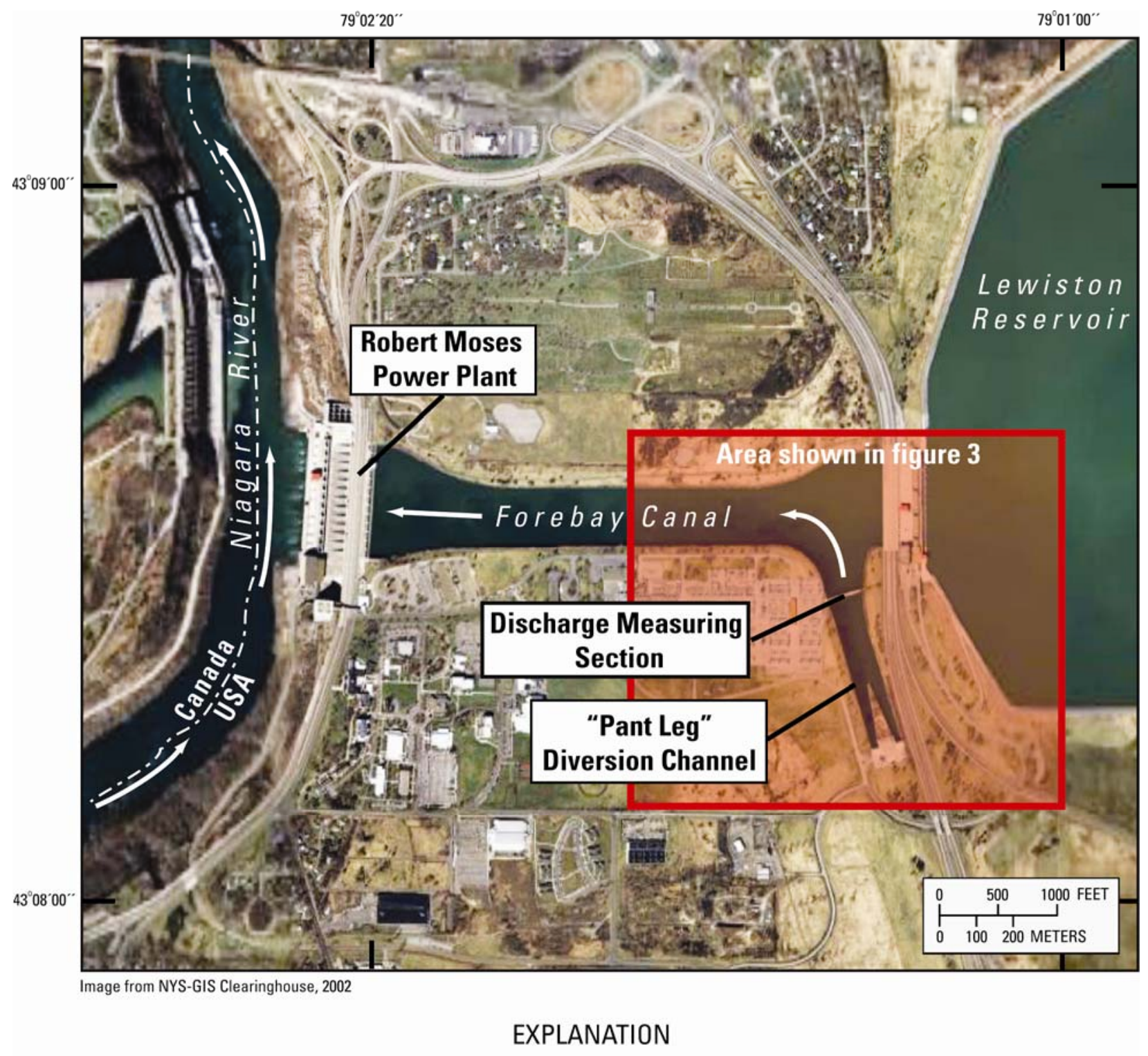

\section{Direction of flow}

Figure 2. Location of Lewiston Reservoir, Forebay Canal, Robert Moses Power Plant, and "Pant Leg" diversion channel area near New York Power Authority Niagara Power Project generation facility, Niagara Falls, N.Y. (Source of the graphic is from the NYS GIS Clearinghouse.) 


\section{Physical Setting}

The Niagara River forms the international boundary between the Province of Ontario and the State of New York (fig. 1). It begins at the mouth of Lake Erie at Buffalo, N.Y., and flows 35.4 mi northward to Lake Ontario. NYPA's Niagara Power Project diverts river water from the area just upstream of Niagara Falls into two 46-ft-wide by 66-ft-high buried, arched conduits that carry the water $4.3 \mathrm{mi}$ to a single open channel called the "Pant Leg" (fig. 2), which, in turn, conveys water 1,700 ft to the Forebay Canal (fig. 2). Depending on the time of day and the day of the week, either all of the water that exits the "Pant Leg" diversion channel is routed through the turbines at the Robert Moses Power Plant at the western end of the Forebay Canal (fig. 2), or some part of that water is pumped up into the adjacent Lewiston Reservoir for later release and power generation, first at the Lewiston Reservoir Power Plant, then at the Robert Moses Power Plant.

The "Pant Leg" channel (fig. 3) is the only reach along this diversion at which measurements of discharge can be made; therefore, it was the focus of this study. This channel is excavated into dolomite bedrock and has vertical walls more than $100 \mathrm{ft}$ high; water depth ranges from 45 to $60 \mathrm{ft}$, depending on power-generation and pumping schedules. The width of this channel at the point where the two conduits converge is $250 \mathrm{ft}$ and increases to $300 \mathrm{ft}$ at the "walkway bridge" that crosses the channel 1,300 ft downstream from the opening of the conduits.

Downstream from the bridge, the channel widens to more than $400 \mathrm{ft}$ where it joins the Forebay Canal (fig. 3).

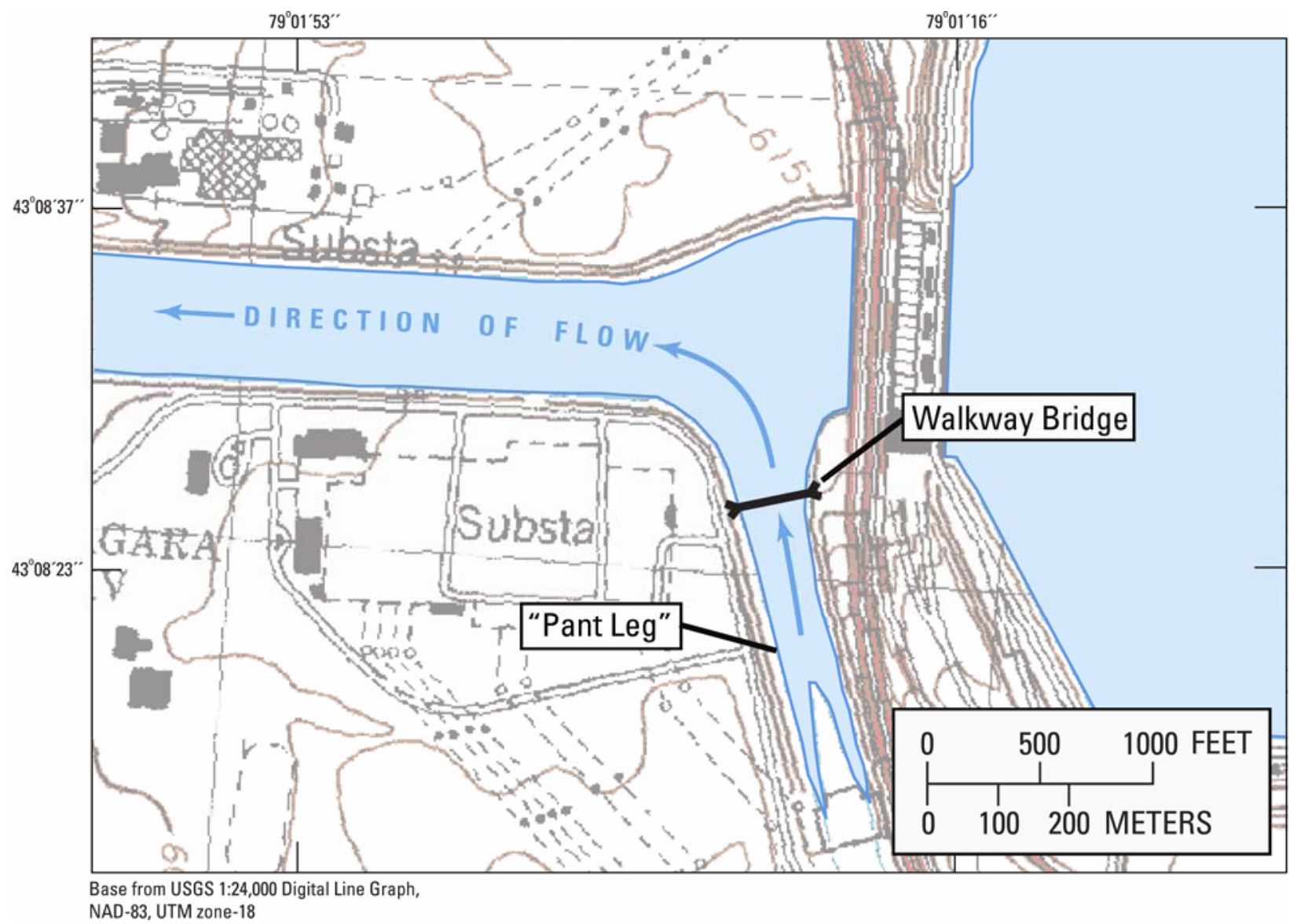

Figure 3. Location of "Pant Leg" diversion channel and walkway discharge measuring section at the New York Power Authority Niagara Power Project generation facility, Niagara Falls, N.Y. 


\section{Purpose and Scope}

This report describes the methods and discusses results of the 3-day tests. The data from each run on each of the 3 days are tabulated in the appendix.

\section{Methods}

ADCP and standard current-meter measurements were made from the walkway bridge that crosses the "Pant Leg" diversion channel because this is the only location at which both types of discharge measurements could be made. Standard USGS procedures were used for both types of measurements, as described below.

\section{Instrumentation}

The acoustic measurements were made by an RD Instruments 600-kilohertz (kHz) ADCP mounted to an Ocean Science trimaran platform that was tethered to the bridge (figs. 4A and 4B). The ADCP unit had a radio link to a laptop computer on the walkway bridge (fig. 4) for transmission of data. The trimaran platform, to which control rope and additional safety rope were attached, was lowered to the water surface from the downstream side of the walkway bridge by a crane supplied by NYPA. The trimaran platform was then allowed to float about $100 \mathrm{ft}$ downstream from the walkway bridge to avoid the effect of any interference caused by the walkway bridge piers. The trimaran platform was towed slowly (about $1 \mathrm{ft}$ per second) across the "Pant Leg" channel by a technician walking across the bridge while the ADCP recorded individual vertical depth and velocity profiles (ensembles) every 1.2 seconds according to the "ping" rate (the time interval between sound-wave pulses from the ADCP equipment). The relatively slow rate of traverse across the channel allowed a large number of depth and velocity measurements to be made and thereby maximized the resolution and, therefore, the accuracy of the computed total discharge. 


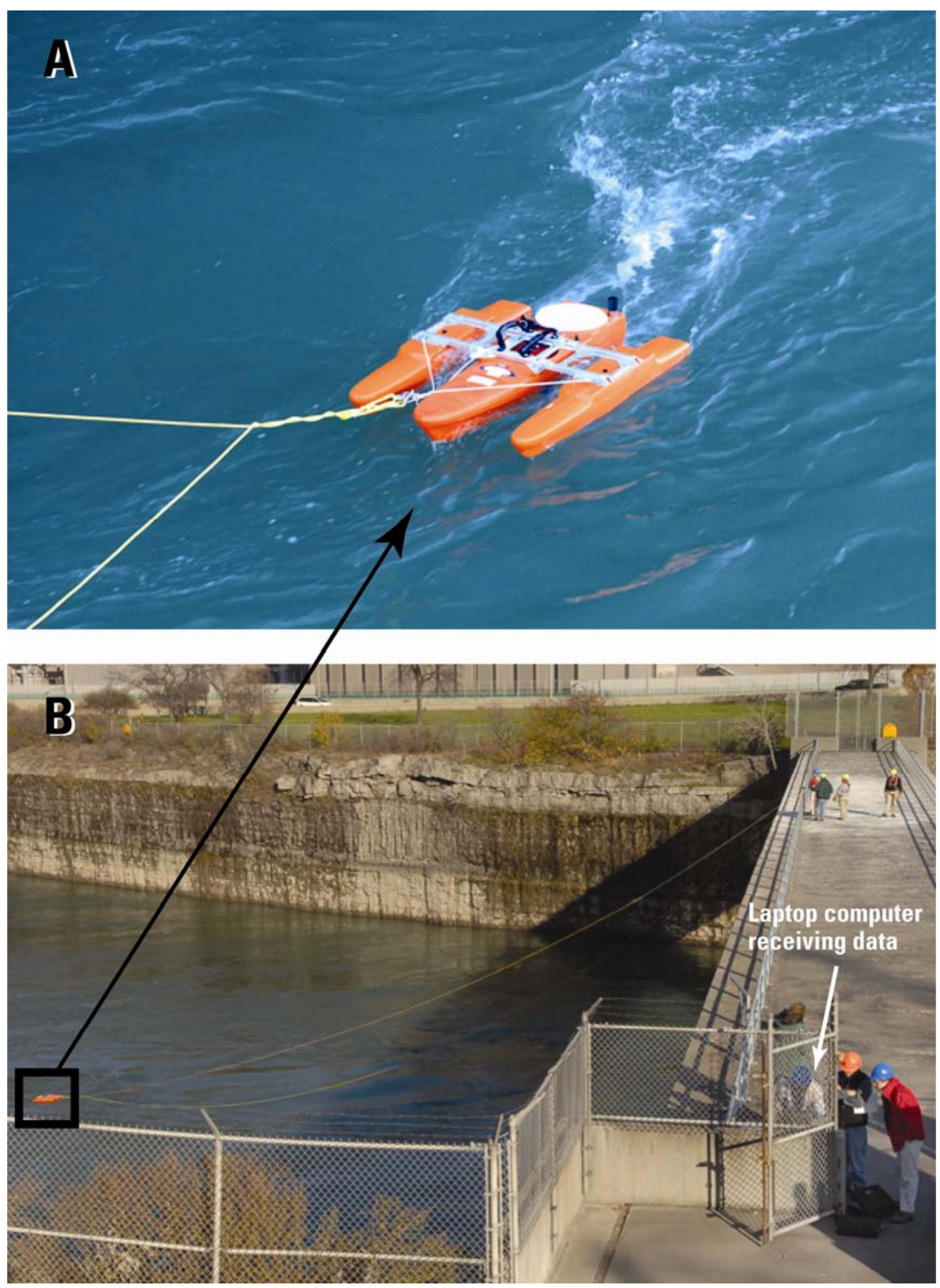

Figure 4. (A) Acoustic Doppler Current Profiler (ADCP) mounted on a tethered trimaran platform that floats on the water surface to measure water velocity and (B) ADCP floating in "Pant Leg" diversion channel downstream from walkway bridge at New York Power Authority Niagara Power Project generation facility, Niagara Falls, N.Y. 
ADCP's measure water velocity acoustically by transmitting pings (sound-wave pulses) into the water column at a specific frequency and recording the time differential for the arrival of the reflected sound from particles suspended in the water. If the particle reflectors are moving closer to or further away from the instrument transducers, the return frequency is Doppler shifted, The ADCP is designed to measure this Doppler shift and compute the velocity and direction of the particle and by extension, the water's velocity (RD Instruments, Inc., 1989). The ADCP is designed to measure three-dimensional velocity profiles, as well as the depth and path the platform make as it navigates the channel. The ADCP measures water velocity in many small "bins" (measurements of velocity magnitude and direction in a given vertical distance in successive vertical subsections for each individual ping) in each vertical ensemble as the instrument is moved across the channel (fig. 5). The individual bins of velocity and area in each ensemble are summed by the ADCP to produce a total discharge for that ensemble. The recorded discharges from all ensembles are then summed to obtain the total discharge across the channel during the measurement period. These discharge values are added to estimates of discharge along the wetted perimeter (edges and bottom) and near the water surface of the channel, which the instrument is unable to measure directly (RD Instruments, Inc., 1989; Simpson and Oltmann, 1992; Morlock, 1996; and Simpson, 2002). 


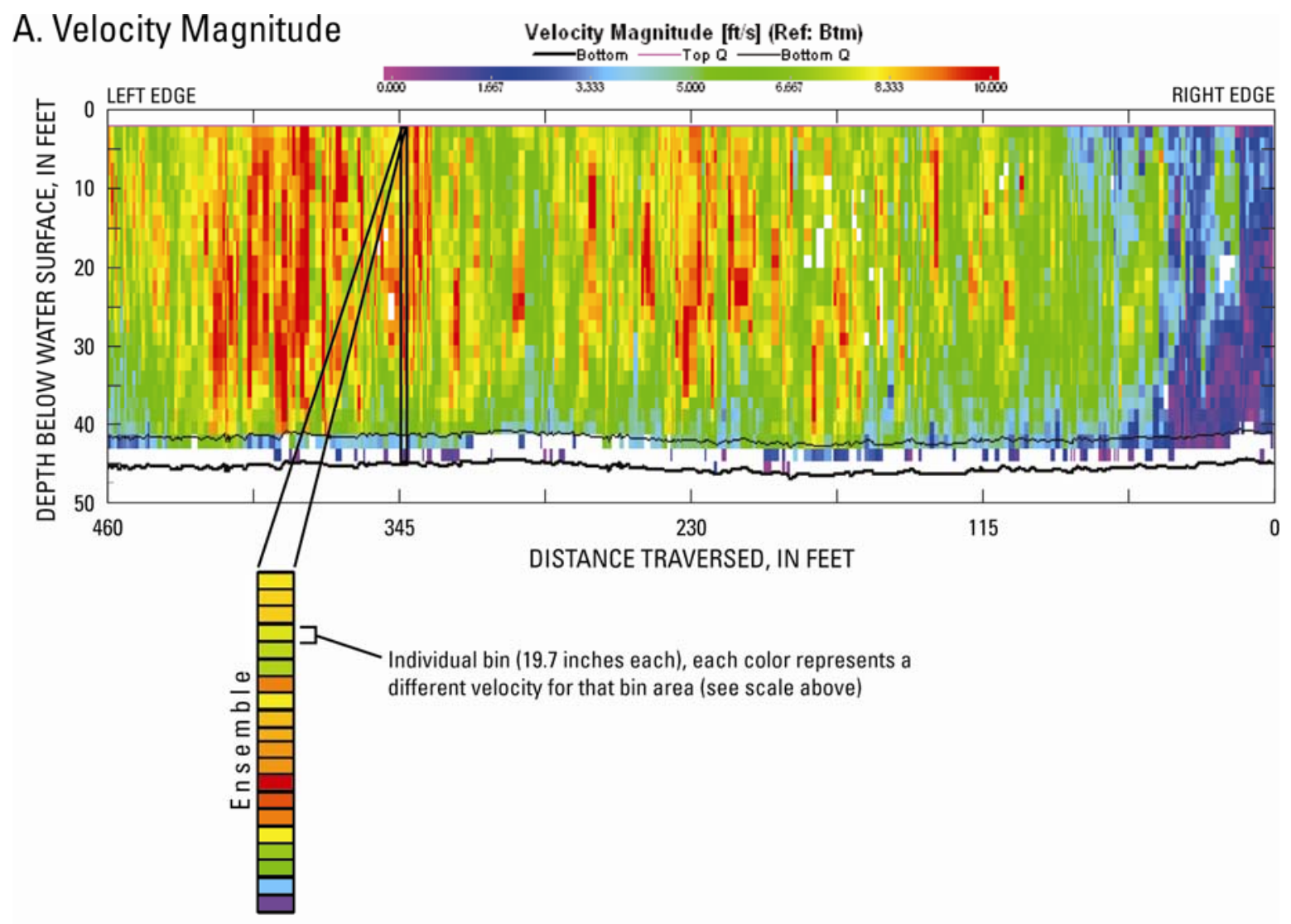

\section{B. Velocity Direction}

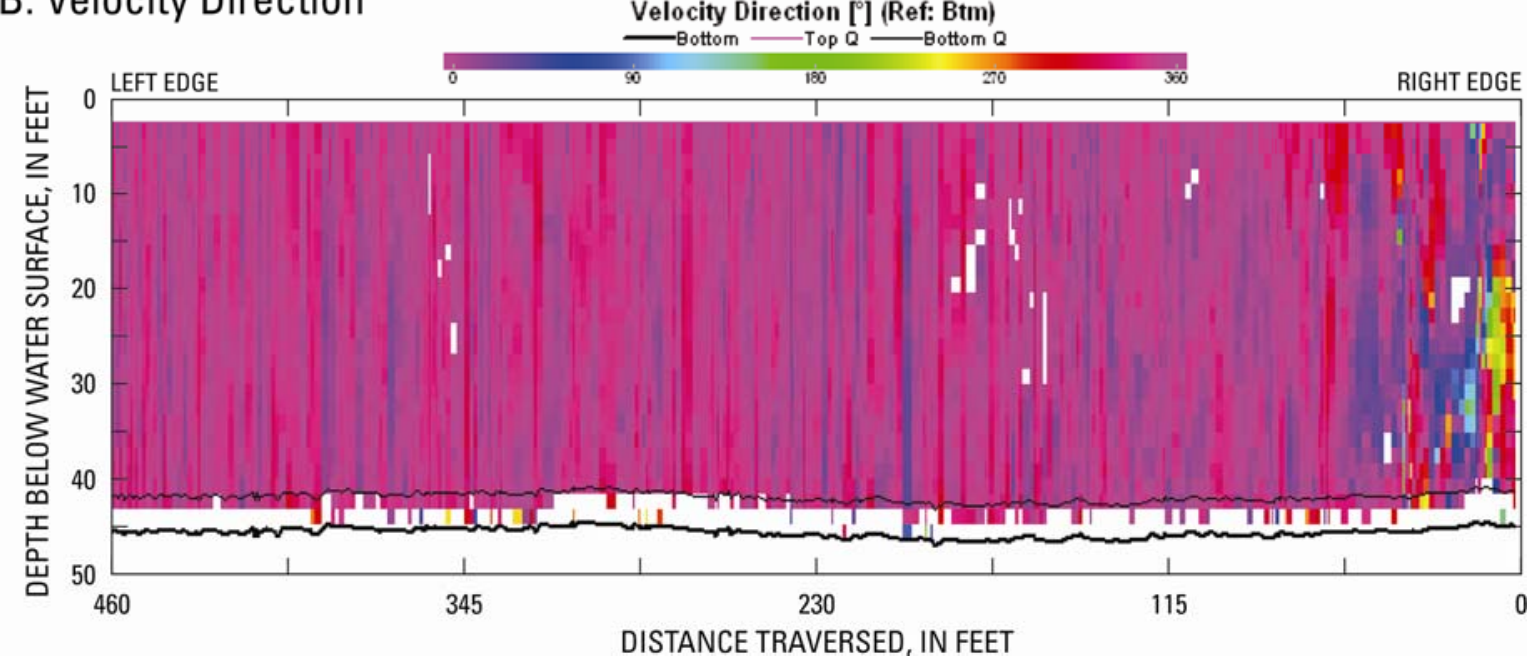

Figure 5. Examples of graphical output (profiles) from Acoustic Doppler Current Profiler (ADCP) showing measured water velocity magnitude, in feet per second $(\mathrm{ft} / \mathrm{s})$, and direction, in degrees $\left({ }^{\circ}\right)$, based on raw ADCP data collected at "Pant Leg" diversion channel near New York Power Authority Niagara Power Project generation facility, Niagara Falls, N.Y., November 7, 2006. (A) Velocity magnitude. (B) Velocity direction. 
The discharge measurement made for comparison with the ADCP measurements was made by a Standard Price-AA current meter suspended by a cable with a 150-pound sounding weight attached to a USGS "E-reel" and bridge crane (fig. 6). The Price-AA current meter consists of a rotor with six cone-shaped cups mounted on a stainless-steel shaft that spin on a pivot. As the water passes by, an electrical contact is made each time the meter cups make a full revolution; thus, the number of revolutions per time unit is a function of the water velocity. Water velocity was measured at two locations, 20 and 80 percent of total depth, in each vertical measuring location along the walkway (every $10 \mathrm{ft}$ ) in the channel cross section (fig. 7).

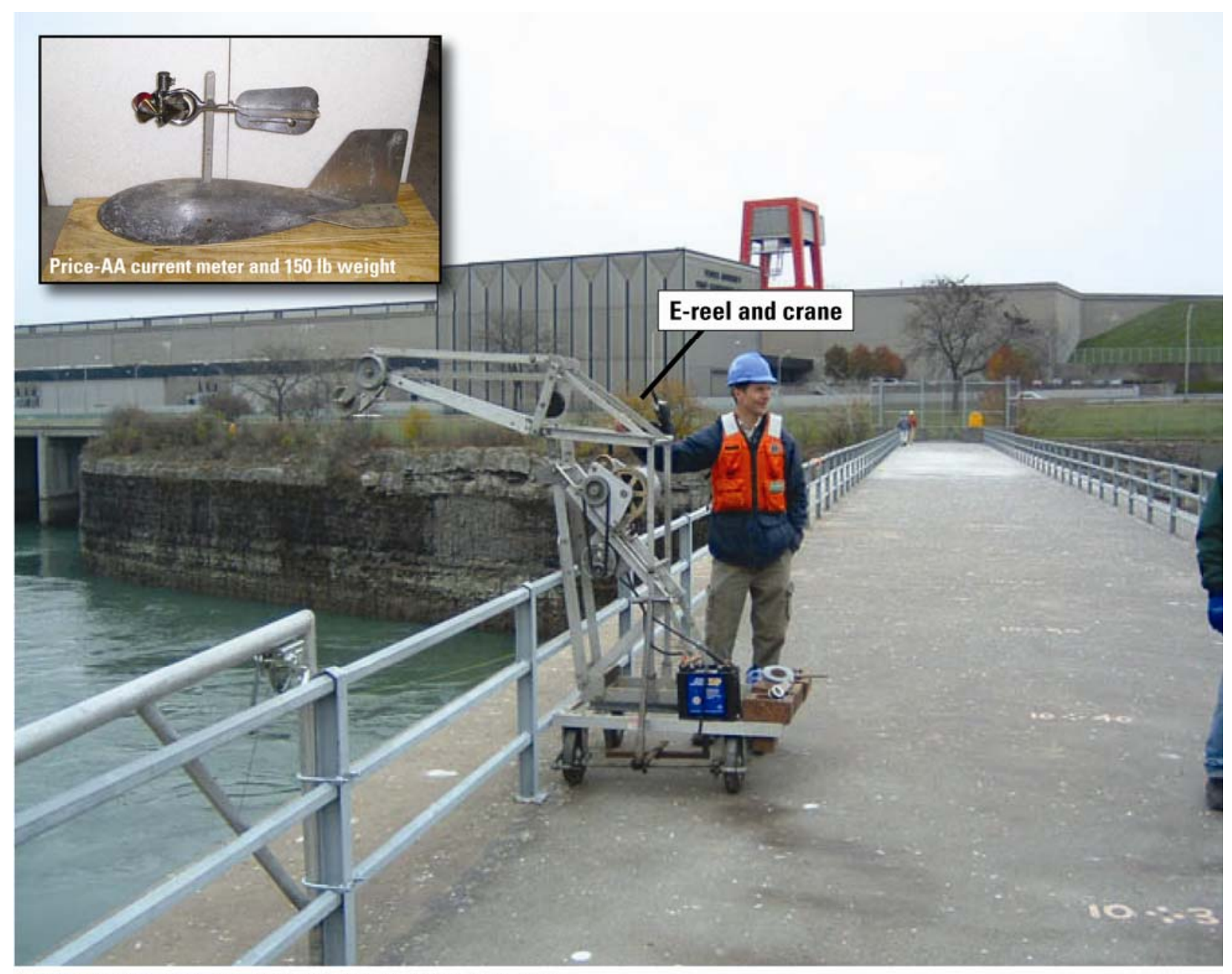

Photographs by H. Zajd, U.S. Geological Survey, November 6, 2006

Figure 6. Measurement setup: Price-AA current meter and sounding weight, E-reel, and E-crane used for standard U.S. Geological Survey current-meter discharge measurement from bridges and used at the "Pant Leg" diversion channel near New York Power Authority Niagara Power Project generation facility, Niagara Falls, N.Y. 


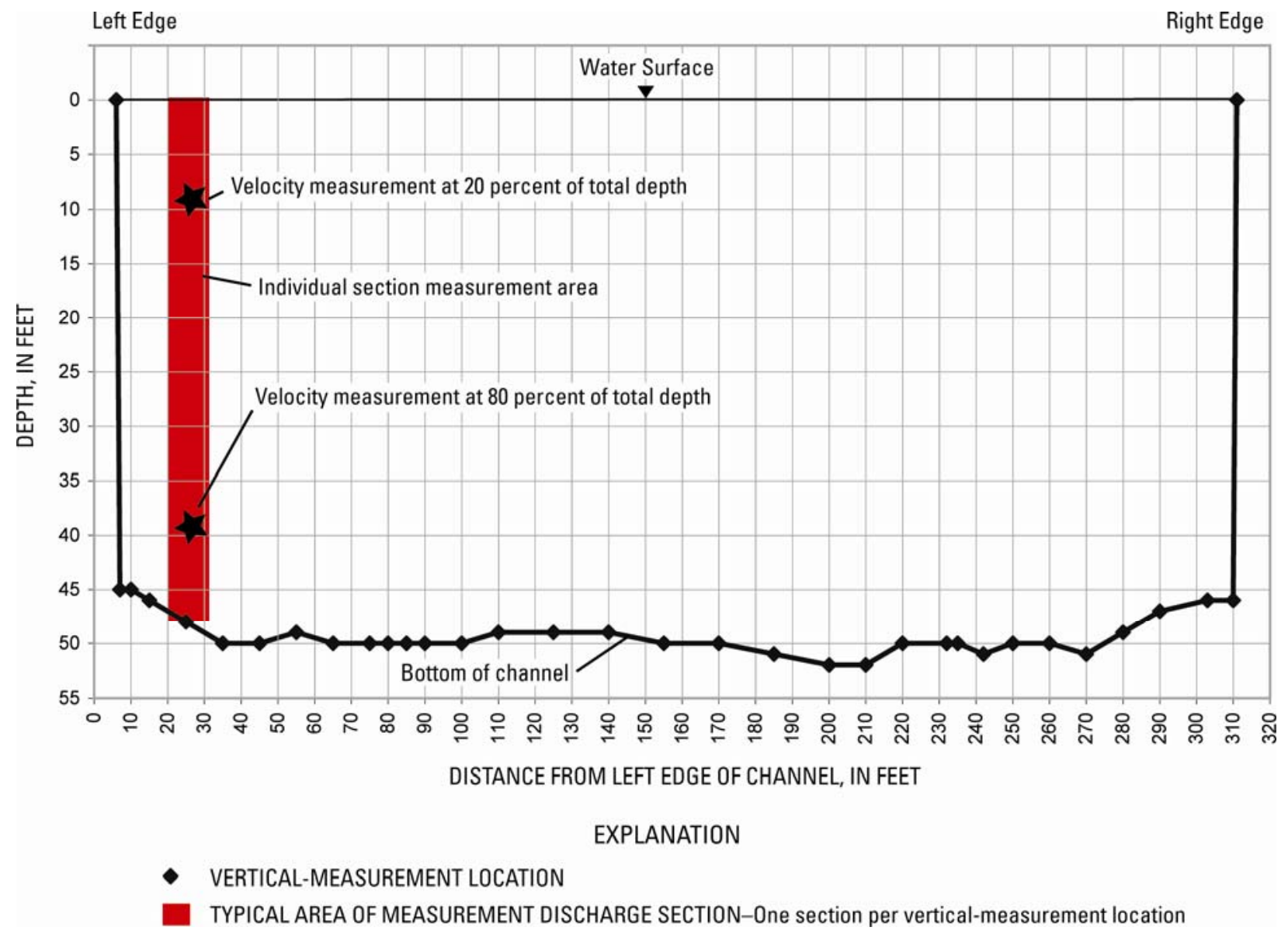

Figure 7. Vertical section of water column showing locations of individual Price-AA current-meter measurements from bridge walkway near the end of Niagara Power Authority "Pant Leg" diversion channel, November 7, 2006, 10:30-12:05 Eastern Standard Time.

The Price-AA current meter was checked before and after the discharge measurement through a standardized spin test in air to indicate whether the cups were able to rotate freely and smoothly until all motion had stopped. This test was timed, and the results are compared with the standard minimum spin time of 1 minute 45 seconds, as prescribed in Rantz (1982). In this study, the meter spun for 2 minutes 45 seconds before the measurement and spun freely afterward; it also showed no sign of damage upon removal from the water after the measurement was completed. The area corresponding to each vertical velocity measurement that is used in the computation of each section's discharge equals the depth at that section multiplied by the average width, which is one-half the distance between the previous vertical section and the next adjacent vertical section (fig. 7). The discharge in each section is calculated as the computed area of that section multiplied by the respective mean velocity in the section. The mean velocity is the mathematical average of the two measured velocities in the section. The total discharge for the channel is then calculated as the sum of values for all sections across the channel, as prescribed in Rantz (1982). 


\section{Measurement Procedures}

Four ADCP measurement sessions from the "Pant Leg" walkway were held during November 6-8, 2006. Each session consisted of 12 to 17 individual ADCP measurements over a period of about 2 hours. ADCP water modes $12 \mathrm{SB}$ (small bin size, $25 \mathrm{~cm}$ ) and RB (regular bin size, $50 \mathrm{~cm}$ ) were chosen for the first session for their general applicability in a variety of channel configurations (U.S. Geological Survey, 2003). Subsequent experimentation with other bin-size settings on November 6, 2006, revealed that mode 12RB was optimal for this site. Therefore, the other three sessions (November 7-8) were made in mode 12RB.

ADCP measurements were made in accordance with published USGS quality-assurance procedures (Oberg and others, 2005). The three major steps are (1) verification of communication between the ADCP and the ADCP software provided on a laptop; (2) performance of a set of pre-described, standard diagnostic tests to ensure that the equipment is operational; (3) selection of an appropriate operational water mode for the ADCP according to channel configuration, depth and velocity. The average discharge for each session (the mean for the several measurements; see appendix) was used to represent discharge over the entire ADCP measurement session. These average ADCP discharges were then compared with the NYPA average for discharge estimates made over the same time period (see next section, "New York Power Authority Method of Calculating Water Diversion"); those estimates are based on water-level changes and turbine efficiencies on an hourly basis (table 1). In addition, one standard USGS current-meter measurement was made on the morning of November 7, 2006 for comparison with the concurrent ADCP measurement session as a quality-assurance test for the discharges reported by the ADCP method.

Table 1. Data from comparison of Acoustic Doppler Current Profiler discharge measurements with discharge calculations by New York Power Authority ${ }^{1}$ at Niagara Power Project generation facility, Niagara Falls, N.Y., November 6-8, 2006.

[ADCP, Acoustic Doppler Current Profiler; NYPA, New York Power Authority. All discharge (Q) values are in cubic feet per second.]

\begin{tabular}{|c|c|c|c|c|c|c|c|c|}
\hline \multirow[b]{3}{*}{ Statistic } & \multicolumn{8}{|c|}{ Date, time (hhmm, eastern standard), and data source } \\
\hline & \multicolumn{2}{|c|}{$\begin{array}{l}11 / 06 / 2006 \\
1445-1604\end{array}$} & \multicolumn{2}{|c|}{$\begin{array}{l}11 / 07 / 2006 \\
1017-1202\end{array}$} & \multicolumn{2}{|c|}{$\begin{array}{l}11 / 07 / 2006 \\
1425-1554\end{array}$} & \multicolumn{2}{|c|}{$\begin{array}{l}11 / 08 / 2006 \\
1017-1112\end{array}$} \\
\hline & ADCP & NYPA & ADCP & NYPA & ADCP & NYPA & ADCP & NYPA \\
\hline $\begin{array}{l}\text { Number of measurements } \\
\text { per session }\end{array}$ & 12 & 2 & 12 & 3 & 17 & 2 & 12 & 2 \\
\hline Range of Q per session & $\begin{array}{l}85,500- \\
94,400\end{array}$ & $\begin{array}{l}83,400- \\
84,700\end{array}$ & $\begin{array}{l}77,000- \\
89,300\end{array}$ & $\begin{array}{l}74,400- \\
83,100\end{array}$ & $\begin{array}{l}87,100- \\
95,400\end{array}$ & $\begin{array}{l}87,300- \\
87,700\end{array}$ & $\begin{array}{l}85,300- \\
91,500\end{array}$ & $\begin{array}{l}83,000- \\
85,100\end{array}$ \\
\hline Mean Q per session & 89,700 & 84,000 & 83,600 & 78,700 & 90,600 & 87,500 & 88,500 & 84,000 \\
\hline $\begin{array}{l}\text { ADCP value minus NYPA } \\
\text { value, in percent }\end{array}$ & +6.8 & & +6.2 & & +3.5 & & +5.4 & \\
\hline
\end{tabular}

'Discharge calculations are hourly and based on an algorithm used by NYPA that includes data from the Forebay and Lewiston Reservoir, and turbine efficiency at Robert Moses and Lewiston powerplants (James Ellis, New York Power Authority, written commun., December 18, 2006). 


\section{New York Power Authority Method of Calculating Water Diversion}

Discharge from the "Pant Leg" channel can be calculated from the Robert Moses power plant output and the changes in the volume of water stored in the Forebay Canal and the Lewiston Reservoir. These river-diversion calculations are made hourly and are based on water-elevation readings to estimate retained water (pondage) as well as the plant's power generation. Watersurface elevation is monitored at the southwestern corner in the following three locations: (1) the Robert Moses power plant tailrace (Niagara River), (2) the Forebay Canal, and (3) the upper (Lewiston) reservoir (fig. 2).

Pondage for the two areas is calculated from the respective elevation readings and data tables. The pondage calculation represents the water volume, derived from elevation differences between the beginning and ending hourly measurements. These pondage volumes are then used in the following calculations to obtain the discharge in the "Pant Leg" diversion channel:

$$
\begin{aligned}
& \text { Reservoir pondage for hour }=\text { Pond }_{(\text {ResBH })}-\text { Pond }_{(\text {ResEH })}, \\
& \text { [function based on volumetric table] } \\
& \text { Forebay pondage for hour }=\text { Pond }{ }_{(F b a y B H)}-\text { Pond }_{(\text {FbayEH })}, \\
& \text { [function based on plant volumetric table }] \\
& \text { Robert Moses plant discharge for hour }=\left(\mathrm{RMHD}_{\text {Avg }} \mathrm{MW}\right) \\
& \text { [Function based on Gibson Test and plant megawatts }(\mathrm{MW}) \text { during the } \\
& \text { period. Note that minute-to-minute scans of water elevations provide } \\
& \text { input head to estimate turbine efficiency for water to power } \\
& \text { output calculation.] } \\
& \text { "Pant Leg" diversion discharge for hour = Robert Moses plant discharge for hour - } \\
& \text { Reservoir pondage }- \text { Forebay pondage }
\end{aligned}
$$

where

$$
\begin{aligned}
\text { ResBH } & =\text { Reservoir beginning of hour elevation } \\
\text { ResEH } & =\text { Reservoir end of hour elevation } \\
\text { FbayBH } & =\text { Forebay beginning of hour elevation } \\
\text { FbayEH } & =\text { Forebay end of hour elevation } \\
\text { RMHD }_{\text {Avg }} & =\text { Robert Moses Plant head average for hour } \\
\text { MW } & =\text { Megawatt }
\end{aligned}
$$


Three factors can lead to errors in the "Pant Leg" diversion calculation:

1. The assumption that water surfaces are level when dynamic load changes (from 400 to 2,400 megawatts) and ice can create oscillations that result in errors in volume calculation. The degree of error depends on the accuracy of the beginning and ending water-level-elevation readings, which might be affected by lag times and oscillating water levels.

2. The dependence of plant-control commands (opening and closing of water-turbine gates) on the diversion-calculation algorithms to establish the next water-level set point.

3. The dependence of the calculation on accurate indexing of individual turbine performance is currently based on only limited test data.

Opportunities to refine plant output control (power generation) and reduce potential errors in the present discharge-measurement system are a key reason why the ADCP measurement may benefit plant operations. (Thomas Key, Electric Power Research Institute, written commun., February 2007).

\section{Acoustic Doppler Current Profiler Measurements in Relation to New York Power Authority Calculations}

Data from all four ADCP measurement sessions (starting and ending time, test duration, channel velocity, flow direction, and total discharge) are given in the appendix; the NYPAcomputed discharges are given for comparison with the ADCP averaged discharges in table 1. Comparison of the ranges of discharges obtained by the ADCP with those obtained by NYPA calculations (table 1) indicates that each ADCP session's discharge varied more widely than the two or three hourly calculated discharges reported by NYPA (fig. 8). The ADCP measurements reflected 37 percent of the entire range of power-generation conditions that NYPA calculated in 2005-06 (fig. 9) (Thomas Key, Electric Power Research Institute, written commun., February 3, 2007). The average of the ADCP measurement-session discharges ranged from 3.5 to 6.8 percent greater than those computed by NYPA for the same period (table 1). The difference between average ADCP discharge and the concurrent discharge measured by current meter on November 7 , 2006 was within 1 percent $\left(84,000 \mathrm{ft}^{3} / \mathrm{s}\right.$ for the ADCP measurement, and $83,600 \mathrm{ft}^{3} / \mathrm{s}$ for the current meter measurement). 

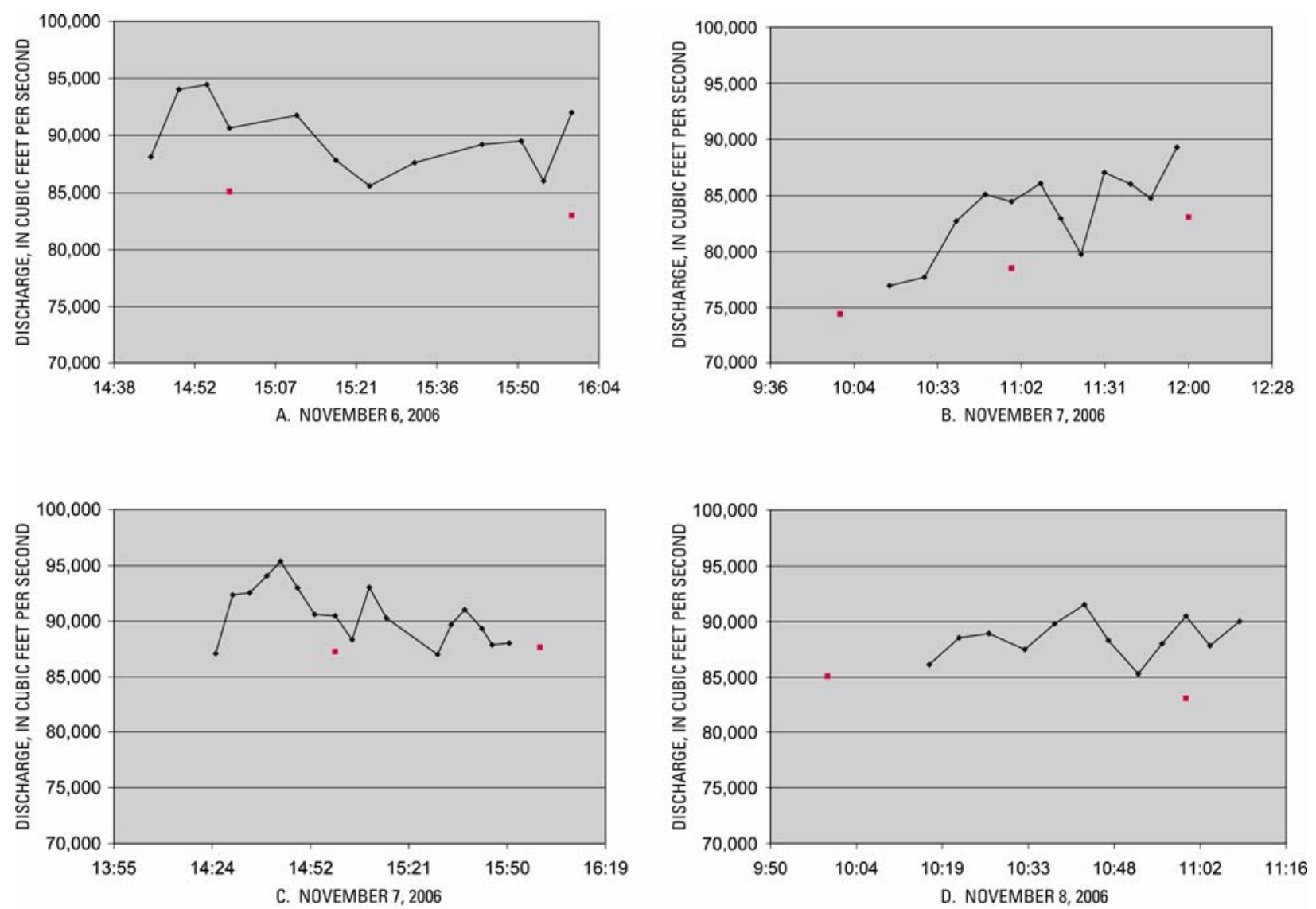

\section{EXPLANATION}

- USGS ADCP discharge measurements

- NYPA calculated discharge

Figure 8. Acoustic Doppler Current Profiler discharge measurements and New York Power Authority (NYPA)-calculated discharges obtained during the four measurement sessions at "Pant Leg" diversion channel near NYPA Niagara Power Project generation facility, Niagara Falls, N.Y., November 6-8, 2006. 


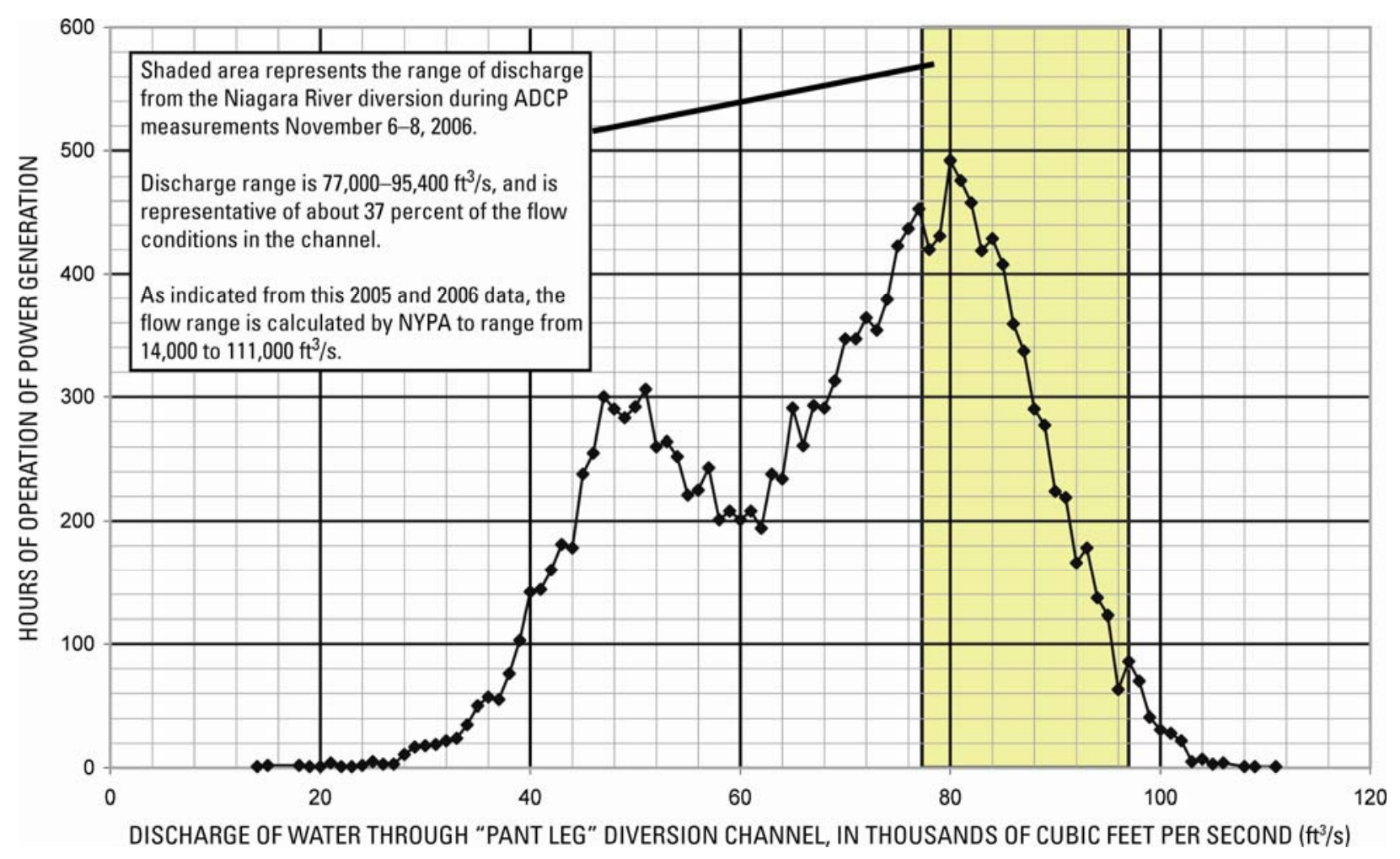

Figure 9. Niagara River Diversion histogram showing 2005-2006 calendar year and discharge rates during Acoustic Doppler Current Profiler measurements in "Pant Leg" diversion channel on November 6, 7, and 8, 2006, near New York Power Authority Niagara Power Project generation facility, Niagara Falls, N.Y.

The discharge close to the channel wall, for an ADCP measurement, cannot be measured accurately because one or more of the four beams from the ADCP impinges on the vertical wall. This beam impingement gives an erroneous value for the measured velocity along the vertical walls; therefore, an erroneous discharge. Standardized methods of the USGS, along with the recommendations of the ADCP manufacturer, imply that accurate measurements near the edges of vertical-walled channels can be made no closer than a horizontal distance equal to the depth of the water along that channel's edge. Guidelines by Fulford and Sauer (1986) and Simpson and Oltmann (1992) call for the first or last measurement of velocity, that is not affected by beam impingement along either edge of the channel wall, to be used in the estimation of discharge. For example, the depth of water along the channel walls in the "Pant Leg" diversion channel ranged from 45 to $50 \mathrm{ft}$; thus, the first and last reliable measurement locations, according to the above recommendation, would be 45 to $50 \mathrm{ft}$ from the edge of the channel.

The "Pant Leg" diversion-channel width at the walkway bridge is just over $300 \mathrm{ft}$ with the water depth along the channel walls of 45 to $50 \mathrm{ft}$. Following the above guidelines meant only 67 percent of the channel width could be measured. Testing of this guideline on November 6, 2006, revealed that beam impingement occurred at $20 \mathrm{ft}$ from the left edge of the vertical wall in the "Pant Leg" diversion channel, and at $30 \mathrm{ft}$ from the right edge, rather than at the 45 to $50 \mathrm{ft}$ prescribed by the standard method (fig. 10). The reduced distance along the "Pant Leg" Channel, 
20 to $30 \mathrm{ft}$ versus 45 to $50 \mathrm{ft}$, increased the percent of measured discharge to about 80 percent. Therefore, this testing increased the accuracy of the ADCP discharge measurement, by decreasing the amount of estimated discharge (fig. 10).

Left edge

Right edge

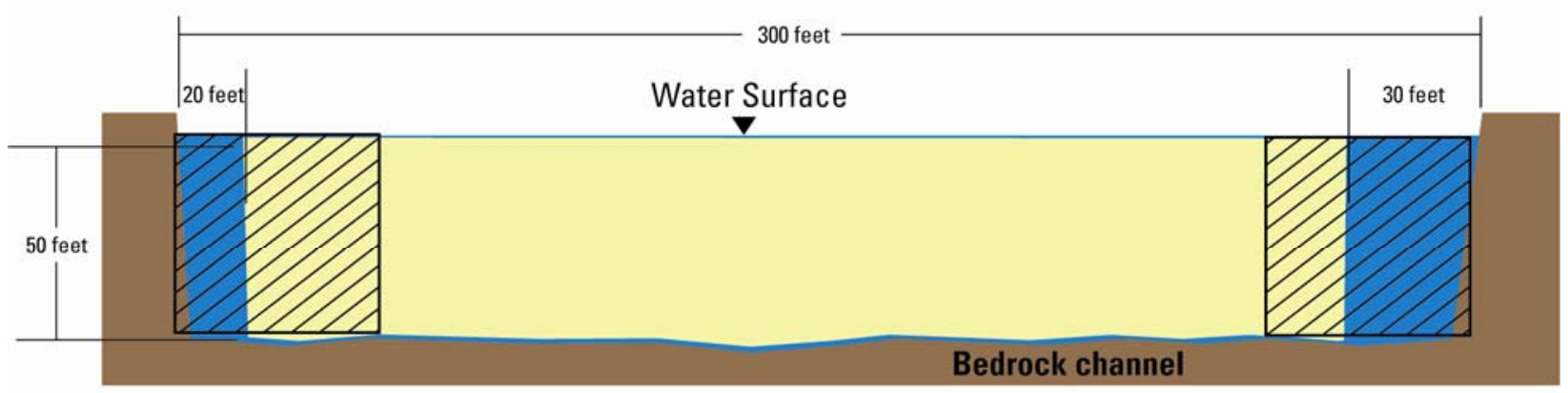

Diagram approximately to scale

Flow is into the page

EXPLANATION

AREA OF MEASURED DISCHARGE

THEORETICAL AREA OF ESTIMATED DISCHARGE-Width of estimated discharge is equal to the depth at that edge.

ACTUAL AREA OF ESTIMATED DISCHARGE-Discharge is estimated from adjacent measured velocities on edges.

Figure 10. Vertical section of "Pant Leg" diversion channel showing area for which the discharge was measured, area for which the discharge theoretically should have been estimated, and area where the discharge was estimated.

In contrast to the above procedure, the current-meter method of discharge measurement required an estimate of discharge within only $5 \mathrm{ft}$ of the left channel wall. A comparison of the ADCP edge discharge value was made with current-meter measurements for the same distance $(20 \mathrm{ft})$, near the left edge of the "Pant Leg" diversion channel and indicated a difference of less than 1 percent $\left(5,500 \mathrm{ft}^{3} / \mathrm{s}\right.$ for the ADCP, and 5,520 $\mathrm{ft}^{3} / \mathrm{s}$ for the current meter). The standard criteria used, and the field and channel conditions at the time of the measurement, indicate that the measurements by both methods could be rated as "good" (95-percent confidence or 5-percent error). 


\section{Summary and Conclusions}

The U.S. Geological Survey (USGS), in cooperation with the Electric Power Research Institute (EPRI) and New York Power Authority (NYPA) tested the effectiveness and accuracy of using an Acoustic Doppler Current Profiler (ADCP) to make discharge measurements in a highvolume water-diversion channel at the NYPA Niagara Falls Power Project at Niagara Falls, N.Y. ADCP measurements were made over 37 percent of the range of power-generation conditions that NYPA had observed between 2005 and 2006. The ADCP was able to measure high-volume discharges accurately in this power-diversion channel. One standard USGS Price-AA current meter on November 7, 2006, made concurrently with a series of ADCP measurements, indicated that the ADCP results were within 1 percent of those obtained by the current-meter technique. The current meter measurement was made as a quality-assurance test for the discharges reported by the ADCP method.

The number of measurements made by the ADCP exceeded the number of hourly calculations normally computed by NYPA; therefore, the ADCP method captured more of the variability in discharge in the "Pant Leg" diversion channel during each 2-hour measurement period. A comparison of the mean ADCP discharge measured during each of the four ADCP measurement sessions with the mean discharge values calculated by NYPA through their standard procedures indicated a difference of 3.5 to 6.8 percent. These results indicate that use of an ADCP can improve the accuracy of discharge measurement in the "Pant Leg" and thereby increase the efficiency of water-management administration for both countries.

The use of ADCP technology proved to be effective within the range of discharges that occurred during that 3-day period; however, the test addressed only a relatively small range of discharge variations and provided "snapshot" values rather than a continuous record. Additional investigation would be needed to indicate whether a permanent installation with a fixed-position ADCP system could provide accurate real-time discharge measurements in this channel. ADCP measurements over the full yearly operational range of the Power Project would be needed to assess whether the differences in discharge measurements by an ADCP and the estimates made by NYPA are constant within ranges beyond those measured during this 3-day study.

\section{Acknowledgments}

Thanks are extended to Thomas Key of the Electric Power Research Institute and to Robert Schwabe, Jiankang Zhu, Joseph Meenaghan, James Rankin, and James Ellis of the New York Power Authority for all their logistical support at the study site, and Neil Watson and Aaron Kennerly of TVGA Consultants, Buffalo, N.Y., for providing general engineering information and logistical support for work at the Niagara Power project. 


\section{References Cited}

Fulford, J.M., and Sauer, V.B., 1986, Comparison of velocity interpolation methods for computing open-channel discharge: U.S. Geological Survey Water-Supply Paper 2090, 154 p.

Morlock, S.E., 1996, Evaluation of Acoustic Doppler Current Profiler's measurements of river discharge: U.S. Geological Survey Water-Resources Investigations Report 95-4218, 37 p.

Oberg, K.A., Morlock, S.E., and Caldwell, W.S., 2005, Quality assurance plan for discharge measurements using Acoustic Doppler Current Profilers: U.S. Geological Survey Scientific Investigations Report 2005-5183, 35 p.

Rantz, S.E., and others 1982, Measurement and computation of streamflow: U.S. Geological Survey Water-Supply Paper 2175, v. 2, 631 p.

R.D. Instruments, Inc., 1989, Acoustic Doppler Current Profiler's principles of operationsA practical primer: San Diego, Calif., RD Instruments, Inc., 36 p.

Simpson, M.R., 2002, Discharge measurements using a broad-band Acoustic Doppler Current Profiler: U.S. Geological Survey Open-File Report 01-01, 123 p.

Simpson, M.R., and Oltmann, R.N., 1992, Discharge measurements using an Acoustic Doppler Current Profiler: U.S. Geological Survey Water-Supply Paper 2395, 34 p.

U.S. Geological Survey, 2003, Release of WinRiver Software version 10.05 for computing streamflow from Acoustic Profiler data: Office of Surface Water Technical Memorandum 2003.04: accessed January 17, 2007, at http://hydroacoustics.usgs.gov/policy/OSW2003-04.pdf 
Appendix. Acoustic Doppler Current Profiler transect start and end times and durations, recorded channel velocities, flow directions, and total discharges, at New York Power Authority Niagara Power Project generation facility, Niagara Falls, N.Y., November 6-8, 2006.

[ft/s, feet per second; $\mathrm{ft}^{3} / \mathrm{s}$, cubic feet per second. Location is shown in fig. 2]

\begin{tabular}{|c|c|c|c|c|c|c|}
\hline File Name & Start Time & End Time & $\begin{array}{c}\text { Transect } \\
\text { duration } \\
\text { [minutes] }\end{array}$ & $\begin{array}{c}\text { Channel } \\
\text { velocity } \\
\text { [ft/s] }\end{array}$ & $\begin{array}{c}\text { Flow } \\
\text { direction } \\
\text { [azimuth] }\end{array}$ & $\begin{array}{c}\text { Total } \\
\text { discharge } \\
{\left[\mathrm{ft}^{3} / \mathrm{s}\right]}\end{array}$ \\
\hline \multicolumn{7}{|c|}{ November 6, 2006 - Measurement Session 1} \\
\hline Nfalls1106001r.000 & $14: 45: 20$ & $14: 49: 45$ & 4.4 & 6.17 & 352.32 & 88,106 \\
\hline Nfalls1106002r.000 & $14: 50: 23$ & $14: 54: 57$ & 4.6 & 6.38 & 351.64 & 94,030 \\
\hline Nfalls1106003r.000 & $14: 55: 22$ & $14: 59: 39$ & 4.3 & 6.41 & 352.89 & 94,448 \\
\hline Nfalls1106004r.000 & $14: 59: 48$ & $15: 04: 37$ & 4.8 & 6.48 & 352.52 & 90,640 \\
\hline Nfalls1106B000r.000 & $15: 11: 58$ & $15: 18: 27$ & 6.5 & 6.92 & 352.04 & 91,739 \\
\hline Nfalls1106B001r.000 & $15: 18: 38$ & $15: 23: 59$ & 5.3 & 6.25 & 351.35 & 87,794 \\
\hline Nfalls1106B002r.000 & $15: 24: 10$ & $15: 31: 13$ & 7.1 & 6.67 & 351.04 & 85,541 \\
\hline Nfalls1106B003r.000 & $15: 32: 14$ & $15: 37: 59$ & 5.8 & 6.24 & 351.69 & 87,590 \\
\hline Nfalls1106C000r.000 & $15: 44: 19$ & $15: 50: 31$ & 6.2 & 6.33 & 349.84 & 89,181 \\
\hline Nfalls1106C001r.000 & $15: 51: 22$ & 15:55:01 & 3.6 & 6.37 & 353.47 & 89,481 \\
\hline Nfalls1106C002r.000 & $15: 55: 14$ & $15: 59: 57$ & 4.7 & 6.36 & 352.1 & 85,982 \\
\hline Nfalls1106C003r.000 & 16:00:50 & $16: 04: 45$ & 3.9 & 6.71 & 353.46 & 91,986 \\
\hline Session Average & & & & & & 89,700 \\
\hline \multicolumn{7}{|c|}{ November 7, 2006 - Measurement Session 2} \\
\hline Nfalls1107001r.000 & $10: 17: 56$ & $10: 28: 11$ & 10.2 & 5.51 & 352.43 & 76,973 \\
\hline Nfalls1107002r.000 & $10: 29: 03$ & $10: 40: 20$ & 11.3 & 5.64 & 353.64 & 77,710 \\
\hline Nfalls1107003r.000 & $10: 40: 51$ & $10: 50: 35$ & 9.7 & 6.21 & 352.75 & 82,736 \\
\hline Nfalls1107004r.000 & $10: 50: 55$ & 10:59:18 & 8.4 & 6.16 & 352.89 & 85,112 \\
\hline Nfalls1107005r.000 & $10: 59: 35$ & 11:07:51 & 8.3 & 6.03 & 352.44 & 84,486 \\
\hline Nfalls1107006r.000 & 11:09:32 & $11: 15: 50$ & 6.3 & 6.27 & 352.29 & 86,030 \\
\hline Nfalls1107007r.000 & 11:16:08 & $11: 23: 20$ & 7.2 & 6.21 & 352.97 & 82,971 \\
\hline Nfalls1107008r.000 & $11: 23: 37$ & $11: 30: 46$ & 7.2 & 5.81 & 351.77 & 79,782 \\
\hline Nfalls1107009r.000 & 11:31:07 & $11: 39: 55$ & 8.8 & 5.65 & 352 & 87,031 \\
\hline Nfalls1107010r.000 & 11:40:16 & $11: 47: 37$ & 7.3 & 6.49 & 350.24 & 85,948 \\
\hline Nfalls1107011r.000 & $11: 47: 53$ & 11:55:56 & 8.1 & 6.55 & 350.91 & 84,790 \\
\hline Nfalls1107012r.000 & $11: 56: 27$ & $12: 02: 54$ & 6.5 & 6.52 & 352.54 & 89,278 \\
\hline Session Average & & & & & & 83,600 \\
\hline
\end{tabular}


Appendix. Acoustic Doppler Current Profiler transect start and end times and durations, recorded channel velocities, flow directions, and total discharges, at New York Power Authority Niagara Power Project generation facility, Niagara Falls, N.Y., November 6-8, 2006.-Continued

[ft/s, feet per second; $\mathrm{ft}^{3} / \mathrm{s}$, cubic feet per second. Location is shown in fig. 2]

\begin{tabular}{|c|c|c|c|c|c|c|}
\hline File Name & Start Time & End Time & $\begin{array}{c}\text { Transect } \\
\text { duration } \\
\text { [minutes] }\end{array}$ & $\begin{array}{c}\text { Channel } \\
\text { velocity } \\
\text { [ft/s] }\end{array}$ & $\begin{array}{c}\text { Flow } \\
\text { direction } \\
\text { [azimuth] }\end{array}$ & $\begin{array}{c}\text { Total } \\
\text { discharge } \\
{\left[\mathrm{ft}^{3} / \mathrm{s}\right]}\end{array}$ \\
\hline \multicolumn{7}{|c|}{ November 7, 2006 - Measurement Session 3} \\
\hline NFalls1107014r.000 & $14: 25: 15$ & $14: 29: 56$ & 4.7 & 6.62 & 353.04 & 87,099 \\
\hline NFalls1107015r.000 & $14: 30: 33$ & $14: 34: 48$ & 4.2 & 7.18 & 352.02 & 92,368 \\
\hline NFalls1107016r.000 & $14: 35: 03$ & $14: 39: 35$ & 4.5 & 6.98 & 353.22 & 92,554 \\
\hline NFalls1107017r.000 & 14:40:02 & $14: 44: 17$ & 4.2 & 7.11 & 352.2 & 94,079 \\
\hline NFalls1107018r.000 & $14: 44: 38$ & $14: 48: 48$ & 4.2 & 6.96 & 353.31 & 95,395 \\
\hline NFalls1107019r.000 & 14:49:11 & $14: 53: 43$ & 4.5 & 7.02 & 353.75 & 92,999 \\
\hline NFalls1107020r.000 & 14:54:01 & $14: 58: 12$ & 4.2 & 7.02 & 353.01 & 90,622 \\
\hline NFalls1107022r.000 & $15: 00: 42$ & $15: 05: 14$ & 4.5 & 7.06 & 353.43 & 90,485 \\
\hline NFalls1107023r.000 & $15: 05: 30$ & 15:09:09 & 3.7 & 7.03 & 352.66 & 88,349 \\
\hline NFalls1107024r.000 & $15: 10: 04$ & $15: 14: 56$ & 4.9 & 7.23 & 353.03 & 93,045 \\
\hline NFalls1107025r.000 & $15: 15: 47$ & $15: 20: 01$ & 4.2 & 6.84 & 353.05 & 90,290 \\
\hline NFalls1107027r.000 & $15: 30: 00$ & $15: 34: 10$ & 4.2 & 6.56 & 352.03 & 87,012 \\
\hline NFalls1107028r.000 & $15: 34: 30$ & $15: 38: 18$ & 3.8 & 6.70 & 352.59 & 89,693 \\
\hline NFalls1107029r.000 & $15: 38: 32$ & $15: 42: 24$ & 3.9 & 6.63 & 351.85 & 91,047 \\
\hline NFalls1107030r.000 & $15: 43: 02$ & $15: 46: 26$ & 3.4 & 6.63 & 352.79 & 89,343 \\
\hline NFalls1107031r.000 & $15: 46: 43$ & $15: 50: 57$ & 4.2 & 6.71 & 352.46 & 87,882 \\
\hline NFalls1107032r.000 & $15: 51: 20$ & $15: 54: 50$ & 3.5 & 6.22 & 352.21 & 88,042 \\
\hline Session Average & & & & & & 90,600 \\
\hline \multicolumn{7}{|c|}{ November 8, 2006 - Measurement Session 4} \\
\hline NFalls1108001r.000 & $10: 17: 12$ & $10: 22: 13$ & 5.0 & 6.14 & 353.71 & 86,123 \\
\hline NFalls1108002r.000 & $10: 22: 50$ & $10: 27: 37$ & 4.8 & 6.25 & 353.72 & 88,552 \\
\hline NFalls1108003r.000 & 10:27:54 & $10: 32: 55$ & 5.0 & 6.27 & 352.98 & 88,929 \\
\hline NFalls1108005r.000 & $10: 33: 55$ & 10:37:59 & 4.1 & 6.34 & 352.8 & 87,497 \\
\hline NFalls1108006r.000 & $10: 38: 16$ & $10: 42: 52$ & 4.6 & 6.52 & 352.82 & 89,806 \\
\hline NFalls1108007r.000 & $10: 43: 13$ & $10: 47: 08$ & 3.9 & 6.55 & 353.78 & 91,535 \\
\hline NFalls1108008r.000 & $10: 47: 27$ & $10: 51: 38$ & 4.2 & 6.28 & 352.75 & 88,312 \\
\hline NFalls1108009r.000 & $10: 52: 17$ & $10: 55: 48$ & 3.5 & 6.07 & 353.28 & 85,290 \\
\hline NFalls1108010r.000 & $10: 56: 14$ & 11:00:10 & 3.9 & 6.17 & 351.93 & 88,014 \\
\hline NFalls1108011r.000 & 11:00:51 & $11: 03: 48$ & 2.9 & 6.19 & 352.57 & 90,498 \\
\hline NFalls1108012r.000 & 11:04:52 & 11:08:51 & 4.0 & 6.16 & 352.3 & 87,843 \\
\hline NFalls1108013r.000 & 11:09:19 & $11: 12: 48$ & 3.5 & 6.57 & 352.92 & 90,024 \\
\hline Session Average & & & & & & 88,500 \\
\hline
\end{tabular}


For more information concerning the research in this report, contact: U.S. Geological Survey

New York Water Science Center

30 Brown Rd.

Ithaca, NY 14850

For information requests:

(518) 285-5602

or visit our Web site at:

http://ny.water.usgs.gov 
